\title{
Characterization of violence suffered by rural zone women in a Brazilian state
}

\section{Caracterização da violência sofrida por mulheres da zona rural de um Estado Brasileiro}

Como citar este artigo: DIAS, LINEKER F.; BARBOSA, KATRICIA B.; OLIVEIRA, THAIISA R. N.; MORAIS, MILENA O. B.; VIEIRA, THAMIRIS S.; FERNANDES, CUSTADO C.; OLIVEIRA, CARLA J. B.; LIMA, CAIO A.; GOBBO, GABRIEL X.; COSTA, JOÃO V. R.; ROSA, MARIA T. N.; OLIVEIRA, STEFAN V. Characterization of violence suffered by rural zone women in a Brazilian state. Revista Saúde (Sta. Maria). 2020; 46 ( 1 ).

Autor correspondente: Nome: Stefan Vilges de Oliveira

E-mail: stefan@ufu.br Telefone: (34) 99233-1818 Formação Profissional: Doutor em Medicina Tropical pela Universidade de Brasilia (UNB), Brasilia, DF, Brasil.

Filiação Institucional: Departamento de Saúde Coletiva, Faculdade de Medicina, Universidade Federal de Uberlândia. Endereço para correspondência: Avenida Pará 1720, Bloco $2 \mathrm{U}$

Bairro: Umuarama

Cidade: Uberlândia

Estado: Minas Gerais

CEP: $38405-320$

Data de Submissão:

1 1/09/2019

Data de aceite:

16/01/2020

Conflito de Interesse: Não há conflito de interesse

\section{ABSTRACT}

Violence is present in many realities and social groups. Therefore, this study seeks to characterize violence against women living in rural areas of Minas Gerais. A descriptive epidemiological study was conducted, with secondary data recorded by the Notification Disease Information System (SINAN) from 2008 to 2017. In 2015, the study was the year with the highest number of reports of violence against women at ages between 25 and 39 years old $(47.8 \%)$, from black ethnicity $(56.92 \%)$ and with lesser school years $(40.43 \%)$. The victims were assaulted mainly on the face $(31.5 \%)$, the aggressor was male $(70.41 \%)$ and violence was committed at the victim's own residence $(81 \%)$, without the use of firearms. In addition, $45 \%$ of women reported that violence was recurrent and that in $39 \%$ of cases the aggressor used alcohol before the aggression. Most cases of violence against rural residents were psychological and/or moral.

KEYWORDS: Domestic violence; Violence against women; Intimate partner violence; Rural population.

\section{RESUMO}

A violência está presente em muitas realidades e grupos sociais. Por isso, este estudo busca caracterizar a violência contra as mulheres moradoras de zona rural de Minas Gerais. Foi realizado um estudo epidemiológico descritivo, com dados secundários registrados pelo Sistema de Informação de Agravos de Notificação (SINAN) de 2008 a 2017. Em 2015 foi 0 ano com o maior número de notificações de violência contra mulheres entre 25 e 39 anos (47,8\%), negras (56,92\%) e menos escolarizadas (40,43\%). As vítimas foram agredidas principalmente na face (31,5\%), o agressor era do sexo masculino (70,41\%), e a violência foi praticada na residência da própria vítima ( $81 \%)$, sem o uso de arma de fogo. Além disso, $45 \%$ das mulheres relataram que a violência era recorrente e que em $39 \%$ dos casos o agressor fazia uso de álcool antes da agressão. A maioria dos casos de violência contra moradoras rurais foi psicológica elou moral.

PALAVRAS-CHAVE: Violência doméstica; Violência contra a mulher; Violência por parceiro íntimo; População rural. 


\section{INTRODUCTION}

According to the World Health Organization (WHO), violence is any action that uses physical force or power, in the form of a threat or concrete act, against the agent himself/herself, another person, a group or community and that generates or can generate suffering, death, psychological damage, impaired development or deprivation 1.

Violence has always been present since the dawn of civilization, initially as a survival form and then as a way of subjugating other subjects².

Thinking about violence in Brazil, despite the universal stereotype of Brazilians as passive, receptive and ethnically tolerant people, historical circumstances such as indigenous contact, slavery in Brazil (1500-1889) and the struggle for the conquest of women's political and social rights in the country were marked by a broad history of violence ${ }^{3}$.

In this scenario, the Ministry of Health (MS) of Brazil implemented in 2006 a system for data collection and statistical analysis of violence cases in the country, creating the Violence and Accident Surveillance System (VIVA)4. It consists of two components: (1) Continuous Surveillance (VIVA Continuous / SINAN), which captures, through a specific Individual Notification Form】, data about interpersonal and self-harm attended at health services, and (2) Sentinel Surveillance (VIVA Survey), which conducts sample surveys every three years in the country's emergency services to identify cases of violence ${ }^{4}$.

Regarding continuous Surveillance, the notification of interpersonal and self-inflicted violence in Brazil was inserted into the Reporting Disease Information System (SINAN) in 2009, which contributed to the expansion of VIVA and ensured the sustainability of notifications of violence in the country ${ }^{4}$. With this actions, the MS has included violence on the National List of Compulsory Notification of Diseases, Diseases and Public Health Events in public and private health services nationwide 4 .

Despite all the progress in understanding and combating violence in the country, according to the Atlas of Violence project, developed by the Institute of Applied Economic Research (IPEA) and the Brazilian Public Security Forum, Brazil still has worrisome data showing that 59,080 homicides were recorded in 2015, equivalent to 28.9 deaths per 100,000 inhabitants ${ }^{6}$.

In this scenario of violence, women are the most susceptible. It can be fundamentally related to the maintenance of unequal power relations existing between genders, which are the result of the construction of social roles in which, historically, men have been privileged over women ${ }^{7}$.

It is also noteworthy that the female population residing in the countryside is even more vulnerable to the occurrence of violence ${ }^{8}$. Studies that evaluated the violence against women living in rural areas in Brazil found out that, the difficulties of accessing primary health care services are aggravated by extreme poverty and unemployment ${ }^{9}$. 
In Brazil, among the strategies to reduce violence against women the creation of the Maria da Penha Law can be highlighted, a law that sought to typify the crime of femicide in the country from $2006^{10}$. However, a study that evaluate the guaranteeing women's rights to life and quality of life as well as access to reference institutions against violence, such as the Women's Police Station in the country, found out that access to these institutions had impeditive factors in the rural setting ${ }^{11}$. The displacement of these women to reference institutions (social or criminal) in cases of violence, the lack of access to information about operation of these institutions, as well as the distance between farm house are factors that contribute to the maintenance of violence against women living in rural areas in Brazil ${ }^{11}$.

Analyzing other studies that evaluated the profile of violence that occurs in rural areas in Brazil, it appears that the studies did not offer results that support a pattern for the generalization of their findings, especially for the violence in rural areas of the country to be broadly characterized ${ }^{12}$.

The knowledge about the characteristics that define this social problem would support the implementation and strengthening of interdisciplinary and integral actions aimed at protecting women living in rural areas, especially to combat domestic violence. Besides, such studies may contribute to improving the quality of life and health of the female population living in the countryside ${ }^{9}$.

Therefore, the present study aims to describe the pattern of violence suffered by women living in rural areas, in the state of Minas Gerais, Brazil, based on secondary data obtained from the Brazilian Reporting Disease Information System (SINAN). It also includes an objective of this study to analyze, based on the scientific literature, the act of violence against women living in rural areas in Minas Gerais and the reasons for this health problem to occur.

\section{METHOD}

This research is a descriptive observational epidemiological study, with secondary data obtained from the Notification Disease Information System (SINAN) collected in the Brazilian state of Minas Gerais (MG), from January 2008 to December 2017.

According to the last census of the Brazilian Institute of Geography and Statistics (IBGE), which counted the Brazilian population in 2010, the total population in Minas Gerais, Brazil, was 19,597,330 inhabitants ${ }^{13}$. This population was distributed in 853 municipalities, of which $85.3 \%$ are urban and $14.7 \%$ rural ${ }^{13}$.

SINAN is the official information system of the Brazilian government responsible for managing epidemiological data used by the Health Surveillance Service. All reported cases of violence in the country's health services constitute a National database that is locally fed in municipalities by the Notification and Epidemiological Investigation of Violence Form ${ }^{5}$. 
The System characterizes violence as any suspected or confirmed case of domestic/intrafamilial, sexual, selfharm, trafficking in persons, slave labor, child labor, torture, legal intervention and homophobic violence against women and men at all ages ${ }^{5}$. In case extra-family or community violence, only violence against children, adolescents, women, the elderly, people with disabilities, indigenous people and LGBT people in Brazil5.

Inclusion criteria for this study were data from violence registered at SINAN from January 2008 to December 2017 against rural women aged 18 to 59 years who suffered physical, moral and psychological violence, in Minas Gerais state, Brazil.

The following variables were selected for the analysis of violence cases: (1) year of occurrence with cases between 2008 and 2017, (2) women aged between 18 and 59 years; (3) victim of female violence; (4) rural resident; (5) cases of violence in rural areas.

This study aimed to characterize women victims of violence in rural areas through the following variables: (1) age, (2) schooling and (3) ethnicity.

Then, the act of violence suffered by the victim was characterized by the following variables: (1) location occurred, (2) there was threat before violence, (3) type of aggression, (4) if physical violence occurred, (5) if psychological violence occurred, (6) if violence is recurrent, (7) use of body force or (8) beating by the aggressor.

Subsequently, the aggressor was characterized by analyzing the variables: (1) sex of the aggressor; (2) used alcohol.

Then, the consequences associated with the episode of aggression were characterized by the following variables: (1) occurrence of post-traumatic stress after aggression; (2) suicide attempts due to aggression; (3) violence resulted in death.

For the analysis of SINAN data, the TabWIN data tab was used, a program provided by the Brazilian MS for statistical health analysis. The construction of graphs and tables was made with the Microsoft Office Excel program. The data was presented by raw numbers, relative and absolute frequencies.

The adjusted incidence per year and the average incidence were calculated. For this, we used information from the Brazilian Demographic Census produced by the Brazilian Institute of Geography and Statistics (IBGE) conducted in 2010, using data from the female population, aged 18 to 59 years, living in rural areas of the state of Minas Gerais. (744,867 women) corrected by 100 thousand inhabitants. Additionally, the lethality of violence per year was calculated.

To carry out the present research work, it is noteworthy that it was not necessary to issue an opinion of the institution a Research Ethics Committee (CEP), given the fact that the data analyzed in the project were derived from a secondary database of the Ministry of Health. Health of Brazil. The data have a non-nominal type, which all Brazilian citizens have access to by the principles of public transparency of consultation on epidemiological data on the health of the country. 


\section{RESULTS}

A total of 10433 cases of violence against women living in rural areas were recorded during the study period. Figure 1 shows a variation from 1 case in 2008 to 2049 cases in 2017. The adjusted average incidence of violence was 140.07 cases for every 100,000 woman rural residents. During this time, 49 deaths from violence were recorded in the historical series studied with an average lethality of $0.05 \%$, and 2015 was the year with the highest number of notifications. Therefore, Figure 1 shows that the year with the highest incidence of violence was 2015, with a value slightly higher than 300 cases. The graph also shows that there was a gradual increase in cases between 2008 and 2015 when, there was a reduction in notifications followed by stabilization in following years.

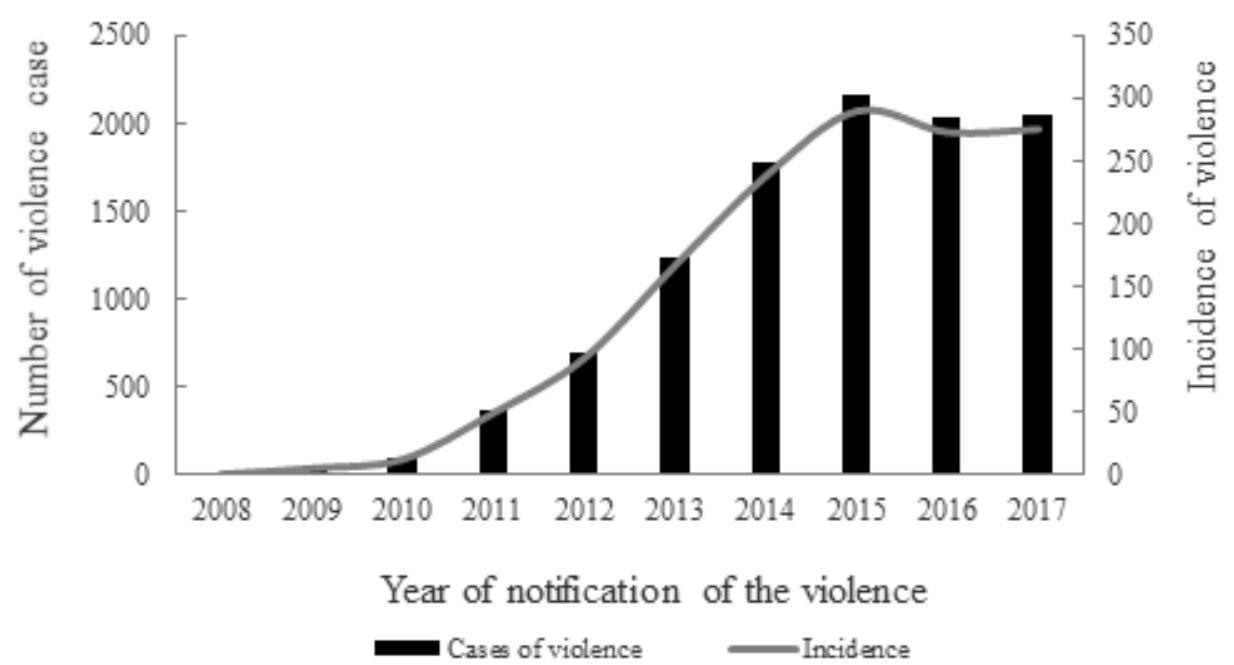

Figure 1: Distribution of cases and incidence of violence against women living in rural areas, notified to the Reporting Disease Information System, in the state of Minas Gerais, Brazil. 2008 to 2017.

Table 1: Distribution of violence against women living in rural areas, according to the analysis variables related to the victim, the aggressor and the forms of aggression, notified to the Reporting Disease Information System in the State of Minas Gerais, Brazil. 2008 to 2017.

\begin{tabular}{lll}
\hline Race of the victim & & Full \\
\hline & White & 3541 \\
& Black & 1412 \\
& Yellow & 95 \\
Brown & 4580 \\
Information ignored or blank & 506
\end{tabular}




\begin{tabular}{|c|c|c|}
\hline Victim's schooling & & \\
\hline & Illiterate & 393 \\
\hline & $1^{a}$ to $4^{a}$ series of high school incomplete & 1590 \\
\hline & $4^{\mathrm{a}}$ serie of high school complete & 1005 \\
\hline & $5^{a}$ to $8^{a}$ series of high school incomplete & 1623 \\
\hline & Complete primary education & 831 \\
\hline & Incomplete high school & 771 \\
\hline & Complete high school & 1172 \\
\hline & Incomplete higher education & 113 \\
\hline & Complete higher education & 119 \\
\hline & Information ignored or blank & 2813 \\
\hline & Not applicable & 3 \\
\hline \multicolumn{3}{|l|}{ Age of the victim } \\
\hline & 18 to 24 years & 2181 \\
\hline & 25 to 39 years & 4987 \\
\hline & 40 a 59 years & 3265 \\
\hline \multicolumn{3}{|c|}{ Local of occurrence of the violence } \\
\hline & Residence & 8453 \\
\hline & Collective housing & 103 \\
\hline & School & 44 \\
\hline & Sports venue & 18 \\
\hline & Bar or similar & 261 \\
\hline & Public roads & 969 \\
\hline & Commerce/Services & 57 \\
\hline & Industries/Construction & 4 \\
\hline & Others & 335 \\
\hline \multicolumn{3}{|c|}{ Did occur threat to the victim before the violence case } \\
\hline & Yes & 2319 \\
\hline & No & 7621 \\
\hline & Information ignored or blank & 493 \\
\hline \multicolumn{3}{|c|}{ Has physical violence occurred } \\
\hline & Yes & 8534 \\
\hline & No & 1789 \\
\hline & Information ignored or blank & 110 \\
\hline \multicolumn{3}{|c|}{ Has moral violence or psychological violence ocurred } \\
\hline & Yes & 4159 \\
\hline & No & 5926 \\
\hline & Information ignored or blank & 348 \\
\hline \multicolumn{3}{|c|}{ Violence is recurrent } \\
\hline & Yes & 4753 \\
\hline & No & 4543 \\
\hline & Information ignored or blank & 1137 \\
\hline
\end{tabular}




\begin{tabular}{|c|c|c|}
\hline \multicolumn{3}{|l|}{ Did the aggressor use a firearm } \\
\hline & Yes & 199 \\
\hline & No & 9710 \\
\hline & Information ignored or blank & 524 \\
\hline \multicolumn{3}{|l|}{ Sex of the aggressor } \\
\hline & Male & 7346 \\
\hline & Female & 2510 \\
\hline & Both sexes & 170 \\
\hline & Information ignored or blank & 407 \\
\hline \multicolumn{3}{|c|}{ Has the use of body strength/ beating occurred by the aggressor } \\
\hline & Yes & 6820 \\
\hline & No & 3335 \\
\hline & Information ignored or blank & 278 \\
\hline \multicolumn{3}{|c|}{ Was violence associated with use of alcohol } \\
\hline & Yes & 4163 \\
\hline & No & 4621 \\
\hline & Information ignored or blank & 1649 \\
\hline \multicolumn{3}{|c|}{ There were any suicide attempt after aggression } \\
\hline & Yes & 273 \\
\hline & No & 2010 \\
\hline & Not applicable & 659 \\
\hline & Information ignored or blank & 7491 \\
\hline \multicolumn{3}{|c|}{ Was there behavior disorder after aggression } \\
\hline & Yes & 176 \\
\hline & No & 2062 \\
\hline & Not applicable & 645 \\
\hline & Information ignored or blank & 7550 \\
\hline \multicolumn{3}{|c|}{ Was there mental disorder after aggression } \\
\hline & Yes & 88 \\
\hline & No & 2135 \\
\hline & Not applicable & 654 \\
\hline & Information ignored or blank & 7556 \\
\hline \multicolumn{3}{|l|}{ Was there post-traumatic stress } \\
\hline & Yes & 403 \\
\hline & No & 1868 \\
\hline & Not applicable & 622 \\
\hline & Information ignored or blank & 7540 \\
\hline \multicolumn{3}{|l|}{ Was death by the violence } \\
\hline & Yes & 49 \\
\hline & No & 3322 \\
\hline & Not applicable & 4 \\
\hline & Information ignored or blank & 7058 \\
\hline
\end{tabular}


Aiming to characterize the woman victim of violence in this region of Brazil, of the cases of violence registered, in $56.92 \%$ of them the race of the victim was black, comprising blacks and browns. When analyzing the victim's education, $40.43 \%$ of them had lower education or even incomplete elementary school (less than 8 years of study). It is also observed that there is a prevalence in the percentage of the victims' age between 25 to 39 years, was $47.8 \%$ of the cases. The second-highest percentage of the victims' age comprises women aged 40 to 59 years, expressing $31.3 \%$ in the records. In analyzing the act of violence itself, Table 1 describes the demographic characteristics of the perpetrator and the places where these aggressions occurred. The data showed that in $81 \%$ of cases the violence occurred in the victim's house. It is also possible to verify from the records of that violence, in $22.23 \%$ of the cases, there were previous threats to violence. During the historical series of the data, the type of violence suffered by women, was mostly physical, which makes up $81.8 \%$ of the cases. While in addressing the type of violence, the psychological comprised $39.86 \%$ of cases. Moreover, in $45.56 \%$ of cases, this violence was recurrent and in $43.54 \%$ it was the first case of violence. Regarding who committed the violence, male perpetrators make up $70.41 \%$ of cases the perpetrators; in $65.37 \%$ it happened the use of body force and/or beatings of the victim. It is also noteworthy that the aggressor was under the influence of alcohol in $39.9 \%$ of the registered cases.

Finally, when analyzing Figure 2, it can be seen that the body parts most frequently affected in the act of aggression were the head and face of women $(31.50 \%)$. It is also important that in $14.03 \%$ of cases violence has affected multiple body regions.

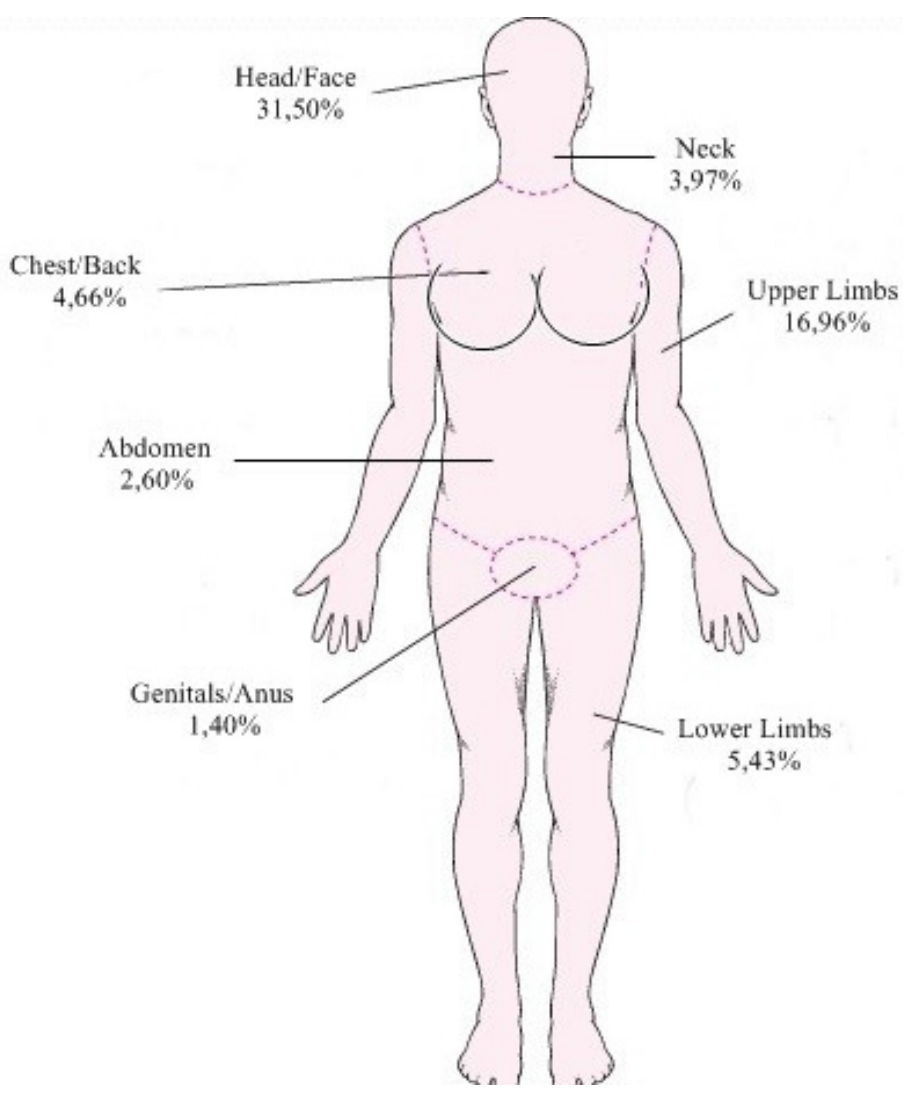

Figure 2 - Distribution of violence against the elderly cases according to the body part most affected. Data from SINAN between 2007 and 2017. 


\section{DISCUSSION}

The general assessment of cases of violence against women in Minas Gerais, Brazil.

Analyzing similar research papers, researchers who sought to analyze the Notification Disease Information System (SINAN), in Minas Gerais, to establish a profile of the grievance of violence against women living in this Brazilian State, between the years 2011 to 2012, found out that most cases of violence, greater than $62 \%$ of cases, occurred at the victim's residence ${ }^{14}$. This result is in line with the findings of this research. Furthermore, researches that sought to analyze the profile of violence against Brazilian women, however, analyzing data from SINAN throughout the national territory, found that in Brazil, in the year 2011, the highest percentage of victims was a white race $(54.6 \%)^{15}$. However, this data goes against the findings of this research in which women of the black race was the highest percentage of victims, totalizing $44 \%$ of reported cases.

This research initially found that, from the frequency of reports of aggression against women living in rural areas in Minas Gerais, Brazil, per year of the occurrence of violence, 2015 was the year with the highest rate of reported cases. In this context, authors, who tried to analyze the applicability of public policies aimed at combating violence against women in Brazil, had highlighted the need for more public servants to assist victims in services related to this theme. Furthermore, the same authors reinforce the importance of adequate training of these workers to serve more effectively the women who come to these public agencies, from the perspective of solving their problems associated with violence and, in association, providing a better reception to the victim of violence to analyze their complaints ${ }^{16}$. In this perspective, it is possible to deduce that the lack of training of civil servants, as well as more adequate physical spaces to provide care to woman victim of violence, can justify the high values presented in this paper, especially in the year 2015. This also suggests that these problems might be getting worse in the State of Minas Gerais, Brazil, especially, from the perspective of nonresolution of this problem, which continues to increase year after year in the Brazilian state analyzed. The effectiveness of implemented public policies, that sought to reduce these values, was not enough, numerically speaking when analyzing the values found in this research.

Characterization of women victim of violence, who live in rural areas, in Minas Gerais, Brazil.

This research showed that, when analyzing the detailed age of women victims of violence, living in rural areas in Minas Gerais, Brazil (Figure 2), the group of women in the age group between 22 and 38 years, represented the largest portion of victims of acts of aggression. Similar research presented consistent data with those presented here, reinforcing 
the age of 20 to 40 years as age group corresponding to the highest number of notifications of violence against women ${ }^{17}$. Among the factors associated with the aggravation of violence, jealousy could be the trigger for aggression against young adult women and, in contrast, with increasing age, the maintenance of aggression could be the result of normalization of this behavior by the victim, who has hopes that the perpetrator will assume a new posture and abandon violent behavior, even after years of maintenance of this behavior by him $^{18}$.

In the perspective of problematizing the victim's age, one hypothesis raised to explain these findings is that as women get older, they become more economically productive and socially influential, and so less likely to report recent violence than younger women. By that way, even if they had already been exposed to domestic violence, older women may have had the opportunity to disengage from this condition because of their greater financial independence 19. Furthermore, it is noted that independence, not only economical but social, can be an obstacle to women's detachment from these vicious cycles of violence.

In this study, it was also observed that of the most women victims of violence in rural areas analyzed were of black race. When problematizing this finding, authors point out that, in many cases, black race woman's who comes to the health services is not well received due to the lack of cultural sensitivity of professionals who serve her and neglect the sociocultural context of the life of the person from another race ${ }^{20}$. This lack of preparation of the health professional when approaching people of another race or ethnicity who suffer violence resulting from a wide sociocultural complexity, such as violence against brown women, may have contributed to the findings of this research, particular associated to the higher percentage of women of this race victims of violence in Minas Gerais, Brazil.

Still characterizing the women victim of violence in this Brazilian state, it was found that nearly half of women victims of violence had lower education or even incomplete elementary school. Reflecting on this finding, it is relevant to note that education has an important social instructive role, allowing for the mitigation of violence as it makes victims who suffer it capable of understanding the complexity of this phenomenon, as well as identify the various types of violence that are subject to suffer ${ }^{21}$. Besides that, education is associated with greater social justice, access to better-paid jobs and empowerment of victims of violence to stop this cycle of aggression ${ }^{21}$. Therefore, the results of our work point to the need for the greater and better educational formation of rural women in the State of Minas Gerais, Brazil, to interrupt and reduce the rates of violence found in this Brazilian state.

Problematizing the act of violence against rural women in Minas Gerais, Brazil.

Analyzing the act of violence itself against the rural woman in Minas Gerais, Brazil, in large majority the cases, the violence occurred at the victim's residence. In this regard, it is important to understand that violence against women is often passed on through generations in their own home and in the victim's own family life, who has been experiencing this 
act since his childhood ${ }^{22}$. This confers a normative character by the woman for this behavior when filed, in the future, by their abusive partners, also in their homes ${ }^{22}$. In this aspect, the violent behavior is normalized until it ends in the actual act of violence against the victim ${ }^{22}$. Such problematization finds subsidy in table 2 which, accordingly, points out that in nearly half of cases the victim reported that the violence recorrency.

By, analyzing the act of violence, this study showed that it was associated with alcohol these cases of in the State of Minas Gerais. Researches have shown that the victim who suffers from violence associated with the use of alcohol often does not report the occurrence of this injury due to the shame of violence associated with psychoactive substance $u^{2} e^{23}$. In this bias, it is possible that the data found in this research, concerning violence against women associated with alcohol use, are even greater in the Brazilian state analyzed, due to under reporting.

The violence suffered by women and associated with partner alcohol use often results from the potentiating effect of aggressive behavior that alcohol stimulates in partners ${ }^{24}$. Studies also point out that woman who is the victim of violence by their partner, secondary to alcohol intake by him, may suffer it by questioning him about drinking alcohol; aggression occurs because the partner does not accept being questioned about it ${ }^{24}$.

Moreover, social and educational measures that aim to orient women about the vulnerabilities to which they are susceptible when their partners make indiscriminate use of alcohol drink are relevant to reduce the rates of violence associated with the use of this drink ${ }^{24}$. Besides, socio-educational measures in school settings, where the onset of alcohol consumption by adolescents often occurs, are also relevant for reducing the rates of violence against women associated with alcohol consumption ${ }^{24}$. This is especially intended to prevent the onset of indiscriminate alcohol drinking by adolescents who may subsequently be potential abusers of their partners ${ }^{24}$.

This way, it appears from analyzing the potential factors that justify the rates of violence against women living in rural areas, in Minas Gerais, associated with the use of alcohol, that violence, potentially, may occur because of such questions to his spouses about drinking, as well as the potentiation of an aggressive behavior of the partner who uses alcohol. In order to change this scenario, socio educational measures in rural schools in this Brazilian state, that seeks to raise awareness among its public about the problems associated with the indiscriminate use of drinking, as well as measures of female empowerment, to identify violence secondary to alcohol use by the partner, may eventually contribute to reducing these rates of violence in the State of Minas Gerais.

From the perspective of the analysis of the act of violence itself against women living in rural areas in this Brazilian State, it is emphasized that, the body part most often hit by women victims was their head and face. Forehead and face aggression often occur because it's an area most exposed by the victim ${ }^{25}$. Also, the head represents the individuality of the person, whom the aggressor seeks to injure in the act of aggression ${ }^{25}$.

In this context, it is emphasized that the investigation and identification of facial lesion patterns in assaulted women can facilitate the recognition of victims of domestic violence by health care professionals that attend them in 
health services, providing an approach and eventually social and health intervention to interrupt this cycle of violence ${ }^{25}$. When caring for the victim, practitioners may seek to advise them about the risks of recurrent facial injury, as well as its possible damaging effects at even cerebral level. Thus, aiming at the awareness of these women about the magnitude of the problems related to domestic violence.

Therefore, women victims of aggression in the State of Minas Gerais, who had the forehead and face as the affected area, may have suffered it because of the aggressor's aim to injure a body part representative of the victims. Also, orientations to professionals in this Brazilian State, so that they can recognize more effectively head and face injuries of women, as suggestive of conjugal violence and, subsequently, promoting a healthy and social approach so that this victim can interrupt the cycle of violence, may contribute to reducing the rates of this grievance.

Among the limitations of this research, we highlight the difficulties related to filling out the SINAN Compulsory Notification Form, made by health professionals who serve women victims of violence. That is, especially because who must report the details of the case of violence are the own victims, who may omit certain information about the episode. Additionally, may occur failure to complete the instrument with some details that the victim brings to the service. Besides, under reporting of cases should also be considered.

Finally, the need for future researches to assess this profile of violence in rural areas is anticipated to increase knowledge about this phenomenon and to implement strategies to prevent and reduce this problem. Furthermore, the need of further work on this topic is reinforced so that a professional qualification can be offered to multidisciplinary health service teams working in rural areas, more compatible with the care of this group of victims.

\section{FINAL CONSIDERATIONS}

The survey results showed that occurred an increase in cases of violence against women living in these areas during the analyzed period. These women, in the vast majority, are people with low education and are young adults, aged between 22 and 38 years, of black race. It was also found that the aggressor had, in most cases, some bond with the victim, being, in various notifications, his partner. Besides, the aggressions mostly occurred at the victim's residence and were associated with alcohol use.

In the period analyzed in this study, there was a clear ineffectiveness of public policies aimed at reducing cases of domestic violence in the state of Minas Gerais. As a strategy to reduce these cases of violence, our analyzes suggest that Health Education actions in rural schools in this state, focusing on issues such as awareness about the negative impacts 
of alcoholism and female empowerment to identify and stop cases of domestic violence, can be effective. Besides, training professionals working in public institutions near or located in rural areas, in the State of Minas Gerais, to identify victims of domestic violence with injuries to the face and seeking these services can be effective in reducing the number of cases of this type of injury. Furthermore, these professionals, by identifying these victims, could approach them and propose or establish strategies for interruption and management of the case of domestic violence.

\section{ACKNOULEDGEMENTS}

We thank Henrique Cardoso Marcene for providing a review of the English version of the manuscript.

\section{REFERENCES}

1. World Health Organization. A public health problem. In: Global consultation on violence and health. Geneva, 1996.

2. Griebler CN, Borges JL. Violência contra a mulher: perfil dos envolvidos em boletins de ocorrência da Lei Maria da Penha. Psico. 2013; 44(2).

3. Girianelli VR, Ferreira AP, Vianna MB, Teles N, Erthal RMC, Oliveira MHB. Qualidade das notificações de violências interpessoais e autoprovocada no Estado do Rio de Janeiro, Brasil, 2009-2016. Cad. Saúde Colet. 2018, Rio de Janeiro, 26 (3): 318-326.

4. Brasil. Ministério da Saúde. Sistema de Informação de agravo de Notificação. SINANWEB. http://portalsinan.saude.gov.br/images/documentos/Agravos/via/violencia_v5.pdf. Update: May 17, 2019. Accessed: June 19, 2019.

5. Cerqueira D, Lima RS, Bueno S, Alves PP, Reis M, Cypriano O, et al. Atlas da Violência 2019, Rio de Janeiro, 2019. repositorio.ipea.gov.br/handle/11058/9489.

6. Saffioti HIB. Gênero, patriarcado, violência. São Paulo, SP: Editora Fundação Perseu Abramo; 2004. 
7. Brasil. Política Nacional de Atenção Integral à Saúde da Mulher: Princípios e Diretrizes. Brasília - DF: Ministério da Saúde, 2011.

8. Arboit J, Costa MC, Silva EB, Colomé ICS, Prestes M. Violência doméstica contra mulheres rurais: práticas de cuidado desenvolvidas por agentes comunitários de saúde. Saúde Soc. 2018; 27: 506-517.

9. Brasil. Constituição Federal de 1988. Lei Maria Da Penha. Lei N. `11.340, 2006.

10. Scott P, Rodrigues AC, Saraiva J. Onde mal se ouvem os gritos de socorro: notas sobre a violência contra a mulher em contextos rurais. In: Scott P, Cordeiro R, Menezes M. eds. Gênero e Geração em Contextos Rurais. Florianópolis, SC: Ed Mulheres; 2010. https://www.ufpe.br/fagesufpe/images/documentos/Livros_Fages/genero\%20e\%20g era_0\%20em $\% 20$ contextos $\% 20$ rurais.pdf.

11. Costa MC, Lopes MJM, Soares JSF. Violência contra mulheres rurais: gênero e ações de saúde. Esc Anna Nery. 2015; 19(1): 162-168.

12. IBGE. In: Indicadores sociais municipais: uma análise dos resultados do universo do censo demográfico 2010. 28th ed. Rio de Janeiro, RJ: IBGE, 2011. https://biblioteca.ibge.gov.br/visualizacao/livros/liv54598.pdf. Accessed: February, 2013.

13. Andrade JO, Castro SS, Heitor SFD, Andrade WP, Atihe CC. Indicadores da violência contra a mulher proveniente das notificações dos serviços de saúde de minas gerais- brasil. Texto Contexto Enferm. 2016; 25(3): 1-9.

14. Paiva EA, Silva MMAD, Neves ACMD, Malta DC, Franco Neto TL, Mascarenhas MDM. Violência contra a mulher: análise das notificações realizadas no setor saúde: Brasil. Divulg. Saúde Debate. 2014; 52: 72-87

15. Cifali AC, Garcia TO. Marco normativo e políticas públicas de enfrentamento à violência contra a mulher: Os desafios na efetivação dos direitos. Sistema Penal \& Violência. 2015; 7(2): 137-147.

16. Viana AL, Carvalho E Lira MOS, Vieira MCA, Sarmento SS, de Souza APL. Violência contra a mulher. Rev enferm UFPE on line. Recife. 2018; 12(4): 923-9. 
17. Zancan N, Wassermann V, Quadros de Lima G. A Violência Doméstica a Partir do Discurso de Mulheres Agredidas. Pensando Famílias. 2013; 17(1):63-76.

18. Garcia LP, Duarte EC, Freitas LRS, Silva GDM. Violência doméstica e familiar contra a mulher: estudo de casos e controles com vítimas atendidas em serviços de urgência e emergência. Cad. Saúde Pública. 2016; 32(4).

19. Tavares JSC, Kuratani SMA. Manejo Clínico das Repercussões do Racismo entre Mulheres que se "Tornaram Negras". Psicologia: Ciência e Profissão. 2019; 39: 1-13.

20. Rosenda LC, Nunes Junior TCN, Czapski ARS. Violência, Direitos Humanos e Educação como Forma de Atenuar a Violência. Rev Humanidades \& Inovação. 2019; 6(7)

21. Moreira AMM, Cunha DFS. Entre o Amor e o Sofrer - A Violência contra a Mulher nas Relações Afetivas do Século XXI: Uma Análise à luz da Sociologia Jurídica e da Psicanálise. Rev de Conflitos Sociais e Conflitos. 2018; 4(1): $111-131$.

22. Costa APS, Oliveira DA, Rodrigues MP, Ferreira MAF. Violência doméstica e abuso de álcool e drogas na adolescência. Revista Ciência Plural. 2015; 1(2) :48-56.

23. Carvalho MRS, Oliveira JF, Gomes NP, Santos MM, Estrela FM, Duarte HMS. Interface between conjugal violence and alcohol consumption by the partner. Rev Bras Enferm [Internet]. 2018;71(Suppl 5):2109-15.

24. Cairns AM, Mok JYQ, Welbury RR. Injuries to the head, face, mouth and neck in physically abused children in a community setting. Int J Paediatr Dent. 2005; 15: 310-318.

25. Arosarena OA, Fritsch TA, Hsueh Y, Aynehchi B, Haug R. Maxillofacial Injuries and Violence Against Women. Arch Facial Plast Surg. 2009;11(1):48-52. doi:10.1001/archfacial.2008.507. 